\title{
A LATE IRON AGE GRAVE WITH HUMAN REMAINS FROM APAHIDA IN THE COLLECTION OF ENDRE OROSZ*
}

\author{
S Á N D O R B E R E C K I ${ }^{(0)}$
}

In 2015, the grandchildren of Endre Orosz, a self-thought archaeologist and collector who operated mainly in Cluj County, donated his archaeological collection to the Mureş County Museum. Cremated human remains of one of the Late Iron Age graves in Apahida, Transylvania were also found among the finds. From the nearly one hundred Late Iron Age graves, this is the only known find suitable for anthropological analyses.

Keywords: Romania, Late Iron Age, Celts, human bones, cremation.

The Late Iron Age cemetery in Apahida, Transylvania, was unearthed in 1900 during work in the gravel mine. Initially, a local teacher, Endre Orosz, collected the finds from the site, and later 21 graves were excavated under the direction of István Kovács (1911). In the years after the excavations, new graves were unearthed, most of the finds of which were also found in the Orosz collection. Because Orosz recorded the finds by the day they turned up, in most cases it is not possible to determine whether the items unearthed on one day belonged to one or more graves, as well as whether all the items from one grave were included in his collection.

The same is true for the two vessels found in the Orosz collection, unearthed on Saturday, $24^{\text {th }}$ March 1900. In 1947, Vlad Zirra, archaeologist at the Institute of Archaeology in Bucharest, researched the collection at Cluj, found a (today missing) note of E. Orosz according to which on that day a large, wheel-thrown vessel was found together with a smaller, handmade vessel inside (Zirra 1967, fig. 47: 6; 1976, 141, 142, fig. 10: 7, 8). In 2015, when the Orosz collection was donated to the Mureş County Museum by the descendants of the family (Berecki/Horti/Kacsó/Nyulas 2017), the handmade vessel was no longer in the collection, only the wheel-thrown vessel and the cremated bones belonging to the grave could be found.

Based on the grave inventories collected by Orosz in the Apahida cemetery, barely a half-dozen graves with handmade vessels can be assumed, while none of the 21 graves unearthed during the excavations of Kovács contained handmade wares. Among the objects unearthed on $28^{\text {th }}$ March 1900, along with the large handmade urn with four knobs, was a small jug, also handmade, while on $25^{\text {th }}$ March 1914 a large handmade urn and a handmade jug was found. Two handmade vessels found by Orosz were sent to the museum in Aiud/Nagyenyed (Alba County), unfortunately no information has survived about their find circumstances.

The eight-knobbed, inverted truncated coneshaped, $90 \mathrm{~mm}$ high cup (Fig. 1: 1; Crişan 1971, fig. V: 2; Zirra 1976, fig. 10: 8), unearthed on $24^{\text {th }}$ March 1900 belongs to the type Németi-C2/C3 (Németi $1988 a, 97$, with analogies). This pottery form is

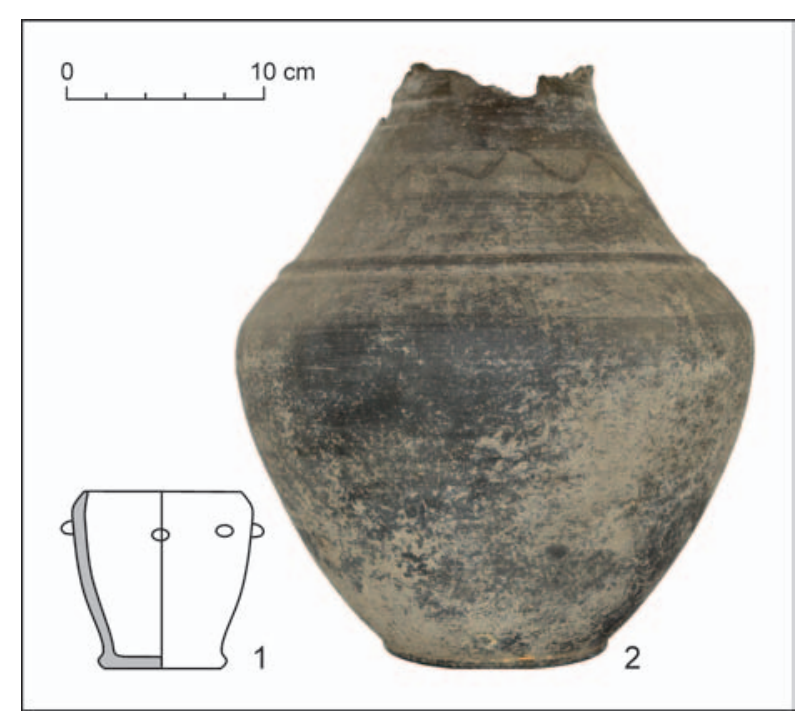

Fig. 1. Apahida. The vessels recovered by E. Orosz on $24^{\text {th }}$ March 1900 (drawing after Zirra 1976).

\footnotetext{
* This work was supported by a grant of the Ministry of Research and Innovation, CNCS - UEFISCDI, project number PNIII-P4-ID-PCE-2020-0566, within PNCDI III. I warmly thank Szilárd-Sándor Gál (Mureş County Museum) for the analysis of the anthropological analysis and Imola Kelemen (Szekler Museum of Ciuc) for the archaeozoological analysis.
} 
characteristic for the late period of the Early Iron Age, and it is also found in La Tène grave inventories. In the Pişcolt/Piskolt cemetery (Satu Mare county) this pottery type appears mainly in the early LT graves (Németi 1988b, 54, 61, fig. 6: M139: 6, 8; 10: M202: 8; 1989, 86, fig. 10: M151: 2, 3), but it was also found in LTC burials (Németi 1992, 62, fig. 3: M20: 10). Late Iron Age vessels of this type are between 70 and $110 \mathrm{~mm}$ high, their colour is mostly brick red or brown and, unlike the eight-knobbed vessel of Apahida, usually have four knobs. In terms of their distribution, it can be observed that during the Late Iron Age they are most common in the cemeteries of the lowlands, west of the Apuseni Mountains (Németi 1988a, 97).

Given that the number of anthropological analyses of Late Iron Age burials in Transylvania is very small, the description of the only known anthropological material of one of the most significant Celtic cemeteries in Transylvania to date could provide important information for later research in this field.

According to the anthropological record, from the cremated bones belonging to the grave found on $24^{\text {th }}$ March 1900 the $85 \%$ of the skeleton is missing. The weight of the 62 bones is $48 \mathrm{~g}$, their dimensions vary between 4 and $39 \mathrm{~mm}$. The bones show a variety of colours ranging from grey-brown to yellow, indicating a burning temperature at $440-525{ }^{\circ} \mathrm{C}$ (phase $3-4$ of heating according to Nicholson 1993; Shipman/Foster/Shoeninger 1984). Among the cremated bones small fragments from the parietal, occipital and frontal bones together with part of the orbits (from the right side) could be identified. The postcranial skeleton is represented by some fragments from long bones, especially their diaphysis or middle part. The ecto- and endocranial sutures and the dimensions of long bones show signs of an adult person. The determination of sex was not possible.

Among the cremated human bones, a mandibular second premolar of a swine was found, indicating the presence of animal offerings in the grave. There is no further information in order to reconstruct the character or composition of the entire animal offering from the grave. In the Late Iron Age graves of the Carpathian Basin the most frequent animal offering is the swine (almost $90 \%$ of the food offerings from this period), then the sheep, hen, cattle, hare and fish (Vörös 2008).

The colour of the cremated bones from Apahida indicate a burning temperature at $440-525^{\circ} \mathrm{C}$. In the case of the cremation graves from Fântânele the temperature of $400-645^{\circ} \mathrm{C}$ is average (Bereckil Vaida 2017, 27, 28). At Ludas, in most cases it was $200{ }^{\circ} \mathrm{C}$ (Tankó 2012, 212), between 200 and $800^{\circ} \mathrm{C}$ at
Hegyfalu (Balázs/Hornok/Tóth 2015, 7), 400-600 C at Zvonimirovo (Šlaus/Novak 2013, 518), and $250-600{ }^{\circ} \mathrm{C}$ sometimes even $700-900{ }^{\circ} \mathrm{C}$ at Dobova (Hincak/Guštin 2011, 250).

The anthropological material from the grave of Apahida fits in all respects the Late Iron Age burial customs of the Carpathian Basin. It can be observed that in this period the amount of bones placed in graves rarely exceeds $20 \%$. Experimental archaeological research has shown that the cremated remains of an adult individual are between 1500 and $3000 \mathrm{~g}$, depending on the intensity of the cremation, in addition to their height and sex (McKinley 1993; Trotter/Hixon 1974).

In the cemetery at Ludas, the weight of the cremated human remains in a grave rarely went above 400 g (Tankó 2012, 212). Likewise, at Mátraszőlős (Almássy 2012) and Hegyfalu (Balázs/Hornok/Tóth 2015) the weight of the cremated bones was below 30 g. In the cremation grave 46A from FântâneleDealul Iuşului only $10 \%$ of the burned human bones were placed (Berecki/Vaida 2017, 27, 28). In the case of prehistoric cremation burials, it can be observed that cremation is always partial, therefore most of the bones remain on the pyre and only soft tissues are consumed by fire.

There is no doubt that there is also a quantitative loss of bones during the archaeological research process and in the laboratory preparation and conservation, but this loss is presumably insignificant in most cases. In the grave from Apahida both the skull and the postcranial skeleton is represented by a few fragments, indicating a tendency for representing the entire body as pars pro toto. This is also indicated by the fact that not only larger pieces were placed in the grave, as there were several pieces smaller than $10 \mathrm{~mm}$ between the bones. Although it is unlikely due to the careful storage methods of Endre Orosz, it cannot be ruled out that in the case of the Apahida finds, the several relocations of the collection may have contributed to the decrease in the amount of the above presented bone material. Yet, probably the small amount of cremated human remains in the grave, a typical aspect of the cremation burials during the Late Iron Age, is more likely to be related to the ceremonial or burial customs of the period (Rebay-Salisbury 2010). It is conceivable that not all the bones were collected from the pyre after the cremation ceremony, but it can also be assumed that not the entire body was cremated.

It can be concluded, that the cremation grave from Apahida found by E. Orosz on $24^{\text {th }}$ March 1900 shows aspects of the widespread and characteristic manipulation of human bodies and burial customs of the $3^{\text {rd }}-2^{\text {nd }} c$. $B C$ in the Carpathian Basin. 


\section{BIBLIOGRAPHY}

Almássy 2012 - K. Almássy: A Mátraszőlős-királydombi kelta temető I. A sírok leírása. A nyíregyházi Jósa András Múzeum Évkönyve 54, 2012, 71-215.

Balázs/Hornok/Tóth 2015 - A. Balázs/P. Hornok/G. Tóth: Birituális La-Téne kori temető Hegyfalu határában (Vas megye). Embertani eredmények. Specimina Electronica Antiquitatis 21, 2015, 1-12.

Berecki/Horti/Kacsó/Nyulas 2017 - S. Berecki/E. Horti/ K. Kacsó/D. Nyulas: Orosz Endre régészeti gyüjteményeColecția arheologică a lui Endre Orosz. Catalogi Musei Marisiensis, series archaeologica III. Cluj-Napoca 2017.

Berecki/Vaida 2017 -S. Berecki/D.-L. Vaida: Morminte duble din a doua epocă a fierului în Bazinul Carpatic - Late Iron Age double burials in the Carpathian Basin. Istros 23, 2017, 13-54.

Crişan 1971 - I. H. Crişan: Necropola celtică de la Apahida. Acta Musei Napocensis 8, 1971, 37-70.

Hincak/Guštin 2011 - Z. Hincak/M. Guštin: Anthropological analysis of Celtic graves from Brežice and Dobova (Slovenia). In: M. Guštin/M. Jevtić (eds.): The Eastern Celts The Communities between the Alps and the Black Sea. Annales Mediterranei. Koper - Beograd 2011, 241-254.

Kovács 1911 - I. Kovács: Az apáhidai őskori telep és La-Tène temetô. Dolgozatok az Erdélyi Nemzeti Múzeum Érem-és Régiségtárából 2, 1911, 1-69.

McKinley 1993 - J. I. McKinley: Bone Fragment Size and Weights of Bone from Modern British Cremations and the Implications for the Interpretation of Archaeological Cremations. International Journal of Osteoarchaeology 3 , 1993, 283-287.

Németi 1988a - I. Németi: Unele aspecte ale evoluției ceramicii din a doua epocă a fierului în nord-vestul R. S. România (Latène B-C). Studii şi Cercetări de Istorie Veche şi Arheologie 39, 1988, 87-111.

Németi 1988 b - I. Németi: Necropola Latène de la Pişcolt, jud. Satu Mare. I. Thraco-Dacica 9, 1988, 49-73.

Németi 1989 - I. Németi: Necropola Latène de la Pişcolt, jud. Satu Mare. II. Thraco-Dacica 10, 1989, 75-114.
Németi 1992 - I. Németi: Necropola Latène de la Pişcolt, jud. Satu Mare. III. Thraco-Dacica 13, 1992, 59-112.

Nicholson 1993 - R. A. Nicholson: Morphological Investigation of Burnt Animal Bone and an Evaluation of its Utility in Archaeology. Journal of Archaeological Science 20, 1993, 411-428.

Rebay-Salisbury 2010 - K. Rebay-Salisbury: Cremations: fragmented bodies in the Bronze and Iron Ages. In: K. Rebay-Salisbury/M. L. S. Sørensen/J. Hughes (eds.): Body Parts and Bodies Whole. Changing Relations and Meanings. Oxford 2010, 64-71.

Shipman/Foster/Shoeninger 1984 - P. Shipman/G. Foster/ M. Shoeninger: Burned Bones and Teeth: An Experimental Study of Colour, Morphology, Crystal Structure and Shrinkage. Journal of Archaeological Science 11, 1984, 307-315.

Šlaus/Novak 2013 - M. Šlaus/M. Novak: Antropološka analiza spaljenih ljudskih kostiju - An archaeological analysis of cremated human bones. In: M. Dizdar: Zvonimirovo-Veliko polje. Groblje latenske kulture - A Cemetery of the La Tène Culture. Zagreb 2013, 513-519.

Tankó 2012 - É. Tankó: L’Étude des trouvailles anthropologiques de la nécropole celtique de Ludas. In: M. Szabó (dir.): La nécropole celtique à Ludas - Varjú-dúlő. Budapest 2012, 197-217.

Trotter/Hixon 1974 - M. Trotter/B. B. Hixon: Sequential Changes in Weight, Density and Percentage Ash Weight of Human Skeletons from an Early Fetal Period Through Old Age. The Anatomical Record 179, 1974, 1-18.

Vörös 2008 - I. Vörös: Offered pigs from the Celtic cemeteries in Hungary. In: Á. Szabó/P. Vargyas (eds.): Cultus deorum studia religionum ad historiam. Vol. I. De Oriente Antiquo et Regione Danuvii Praehistorica. In memoriam István Tóth. Ókortudományi Dolgozatok 1 . Pécs 2008, 303-322.

Zirra 1967 - V. Zirra: Un cimitir celtic în nord-vestul României. Baia Mare 1967.

Zirra 1976 - V. Zirra: La nécropole La Tène d'Apahida. Dacia n. s. 20, 1976, 129-165.

Sándor Berecki, $\mathrm{PhD}$

Muzeul Județean Mureș

str. Mărăşti 8A

RO - 540328, Târgu Mureş

sberecki@yahoo.com 
